\title{
天然甘味料製剤中のステビア成分の分析法
}

(昭和 55 年 5 月 23 日受理)

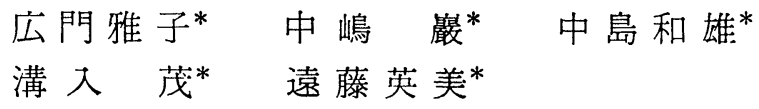

\section{An Analytical Method for Stevia Components in Natural Sweetner Preparation}

\author{
Masako Hirokado, Iwao NaKaJIMA, Kazuo NAKaJima, \\ Shigeru MizoIRI and Fusayoshi Endo
}

(Tokyo Metropolitan Research Laboratory of Public Health: 24-1, Hyakunincho 3-chome, Shinjuku-ku, Tokyo)

\begin{abstract}
An analytical method was established for the detection of stevia components in natural sweetner preparation by thin layer chromatography (TLC) on silica gel. Stevia components were developed with chloroform-methanol-water $(30: 23: 4)$ and detected by spraying the chromatograms with anisaldehyde-sulfuric acid. Five stevia components yielded distinct green spots. The detection limits for these stevia compounds by this method were $0.1 \mu \mathrm{g}$.

High performance liquid chromatography (HPLC) was applied for the quantitative determination of stevioside and rebaudioside $\mathrm{A}$ among stevia components. One gram of natural sweetner preparation was dissolved in $20 \mathrm{ml}$ of $50 \%$ methanol solution and cleaned up by column chromatography on silica gel. Stevia components were eluted from the silica gel column with chloroform-methanol-water $(30: 40: 15)$. Stevioside and rebaudioside $\mathrm{A}$ in the eluate were analyzed quantitatively by HPLC. The analytical conditions for HPLC were as follows: column, Unisil Q-NH detector, $210 \mathrm{~nm}$. The limits of detection by HPLC were $0.1 \mu \mathrm{g}$ of stevioside and $0.2 \mu \mathrm{g}$ of rebaudioside A.

Fourteen commercial products were analyzed. Stevioside, rebaudioside A, B and C and steviolbioside were detected, and quantitative measurements indicated the presence of 0.47 to $37.9 \%$ stevioside and 0.26 to $11.9 \%$ rebaudioside $\mathrm{A}$.
\end{abstract}

(Received May 23, 1980)

\section{まえがき}

ステビアは Stevia rebaudiana BERTONI の葉から 抽出される天然の甘味料で, その甘味度はショ糖（濃度 $2 \%$ ）約 300 倍と強くしかも低カロリーのため, サッ カリンの代替として広い範囲の食品（珍味, 清涼飲料, チューインガム等) に利用されている。

ステビア甘味成分は現在までに 8 種類確認されてお り1)，いずれもステビオール骨格を有するジテルペン配

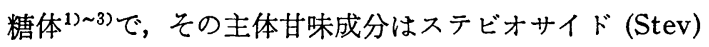

\footnotetext{
*東京都立衛生研究所：東京都新宿区百人町 3-24-1
}

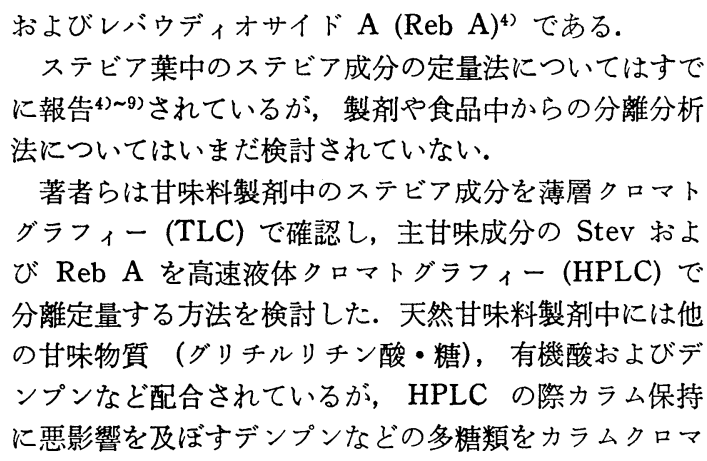

著者らは甘味料製剤中のステビア成分を薄層クロマト グラフィー (TLC) で確認し，主甘味成分の Stev およ び Reb A を高速液体クロマトグラフィー (HPLC) で 分離定量する方法を検討した。天然甘味料製剤中には他 の甘味物質 (グリチルリチン酸・糖)，有機酸およびデ ンプンなど配合されているが， HPLC の際カラム保持 に悪影響を及ぼすデンプンなどの多糖類をカラムクロマ 
トグラフィーで除去し，グリチルリチン酸および有機酸 など酸性物質はプレカラムを用い除去することにより良 好な結果が得られたので報告する。

\section{実験方法}

\section{1. 試料および試薬}

天然甘味料製剂：市販品14種を用いた。

ステビオサイド (Stev)，レバウディオサイド A (Reb A)，レバウディオサイド B (Reb B) およびステビオー ルバイオサイド (Stev-b) 標準品：いずれも丸善化成(株) 製のものをメタノールより再結晶したものを用いた。

グリチルリチン酸（Gly）標準品：グリチルリチン酸 モノアンモニウム（甘草兓話会基準品）をメタノールよ り再結晶した。

Stev, Reb A, Reb B, Stev-b および Gly 標準溶液： 各標準品約 $100 \mathrm{mg}$ をはかり，それぞれに $50 \mathrm{v} / \mathrm{v} \%$ メ タノール $20 \mathrm{ml}$ を加えて水浴上で加熱して溶かした。

Steb-Reb A 標準溶夜: Stev および Reb A 標準品 をそれぞれ約 $100 \mathrm{mg}$ を精密にはかり，これらを合せ $50 \mathrm{v} / \mathrm{v} \%$ ×タノール $15 \mathrm{ml}$ を加えて水浴上で加熱して 溶かし, 冷後 $50 \mathrm{v} / \mathrm{v} \%$ メタノールで $20 \mathrm{ml}$ にメスアッ プした.

グルコース $(\mathrm{G})$ および乳糖 $(\mathrm{L})$ 標準溶液：いずれも 和光純薬工業(株)製のものを用い, $50 \mathrm{v} / \mathrm{v} \%$ メタノール に加熱して溶かし，1\% 溶液とした。

デンプン (S) 標準溶液：可溶性デンプン(和光純薬工 業(株)製) 約 $100 \mathrm{mg}$ をとり， $50 \mathrm{v} / \mathrm{v} \%$ メタノール 10 $\mathrm{ml}$ を加えて水浴上で約 5 分間加熱し，冷後口紙を用い てろ過し，このろ液を用いた。

TLC 用シリカゲル : Merck社製 Kieselgel 60 (20× $20 \mathrm{~cm})$ を $105^{\circ}, 30$ 分間活性化し, デシケーター中で放 冷したものを用いた。

カラムクロマト用シリカゲル：Merck 社製 Kieselgel 40 (70〜230 メッシュ, ASTM) を用いた。

アニスアルデヒド-硫酸：アニスアルデヒド $0.5 \mathrm{ml}$ を $9 \mathrm{ml}$ のエタノールに溶かし， $0.5 \mathrm{ml}$ の硫酸および $0.1 \mathrm{ml}$ の水酢酸を加えた。

その他の試薬：すべて試薬特級を用いた。

\section{2. 器具および装置}

ミリポアフィルター: FH 型, 孔径 $0.5 \mu \mathrm{m}$.

カラムクロマト管: 内径 $2 \mathrm{~cm}$, 長さ $20 \mathrm{~cm}$ のコック 付きガラス管に, Kieselgel 40 のクロロホルム㲘濁液を 流し込み, 高さ $6.5 \mathrm{~cm}$ の層とした後, クロロホルム一 メタノール一水 $(30: 40: 15)$ 混液 $50 \mathrm{ml}$, ついでクロ ロホルムーメタノール (2:1) 混液 $10 \mathrm{ml}$ で順次洗った ものを用いた.

\section{3. 実験操作}

\subsection{TLC による定性法}

試料約 $1 \mathrm{~g}$ を $50 \mathrm{v} / \mathrm{v} \%$ メタノール $20 \mathrm{ml}$ に水浴上 で溶かし，冷後ミリポフフィルターでろ過し，このろ液
を試験溶液とした．次に Stev, Reb A, Reb B, Steb-b Gly, G, L および S 各種標準溶夜および試験溶液それ ぞれ約 $1 \mu \mathrm{l}$ を Kieselgel 薄層板上に別々にスポットし， 展開溶媒クロロホルムーメタノールー水 $(30: 23: 4)$ を 用いて約 $15 \mathrm{~cm}$ (約 2 時間) 展開した. 薄層板を取り出 认風乾後アニスアルデヒドー硫酸を噴霧し， $120^{\circ}, 15$ 分 間加熱した後, スポットの呈色と $R f$ 值よりステビア甘 味成分の確認を行った。

\section{2 定量法}

試験溶液の調製：試料約 $1 \mathrm{~g}$ を精密にはかり， $50 \mathrm{v} / \mathrm{v}$ $\%$ メタノール $15 \mathrm{ml}$ を加え水浴上で約 5 分間加熱し， 冷後 $50 \mathrm{v} / \mathrm{v} \%$ メタノールで $20 \mathrm{ml}$ にメスアップした 後, ミリポアフィルターを用いてろ過し，このろ液を試 験溶液とした。

カラムクロマトグラフィーによる前処理：調製したシ リカゲルカラム (内径 $2 \mathrm{~cm}$, 高さ $6.5 \mathrm{~cm}$ ) に試験溶液 $1 \mathrm{ml}$ を注入し，シリカゲル層表面まで流した。 クロロ ホルムーメタノール $(2: 1)$ 混液 $10 \mathrm{ml}$ でクロマト管内 を洗い (流出速度 $2 \mathrm{ml} / \mathrm{min}$ ), 次いでクロロホルムーメ タノール一水 $(30: 40: 15)$ 混液 $25 \mathrm{ml}$ でステビア甘味 成分を溶出させた（流出速度 $2 \mathrm{ml} / \mathrm{min}$ )。この溶出液を $50^{\circ}$ 以下, 減圧下で濃縮乾固し, 残留物に水 $1 \mathrm{ml}$ を加 えて溶かし，これを検液とした。

HPLC による Stev および Reb A の定量：検液 2 $\mu 1$ を HPLC に注入し, 下記条件下で分析した. 同様に Stev-Reb A 標準溶液を $50 \mathrm{v} / \mathrm{v} \%$ メタノールで希釈し て $0.25,0.5,1,2,2.5 \mathrm{mg} / \mathrm{ml}$ を作製し，それぞれを HPLC に $2 \mu 1$ 注入し, そのピーク高を求め Stev およ び Reb A 量 $(\mu \mathrm{g})$ とピーク高との関係をプロットして 検量線を作成し，その検量線から試料中の Stev および Reb A の含量を求めた.

Operating condition of HPLC

Instrument:

Pump Nihonbunko SP-048 type

Detector Nihonbunko UVIDEC 100-II type, wave-length $210 \mathrm{~nm}$

Column $4 \mathrm{~mm} \phi \times 250 \mathrm{~mm}$, packing material Unisil Q- $\mathrm{NH}_{2}$

Eluent $\mathrm{CH}_{3} \mathrm{CN}-\mathrm{H}_{2} \mathrm{O}(83: 17)$, flow rate 1.2 $\mathrm{ml} / \mathrm{min}$, pressure $70 \mathrm{~kg} / \mathrm{cm}$

\section{実験結果および考察}

\section{TLC の展開溶媒の検討}

Sakamoto $5^{3)}$ が Stevia 葉抽出成分の分離に用いた 展開溶媒クロロホルムーメタノールー水 $(15: 6: 1)$ は ステビア 4 成分のスポットのまとまりは良好だが $R f$ 值 が低く，他の糖との分離が悪いためこの溶媒系について さらに検討を加えて，ステビア 4 成分と他の糖との分離 条件を検討した. メタノールに対し水の比率が非常に高 いと，その混合溶媒は分離を生じ，また水に対しメタノ 


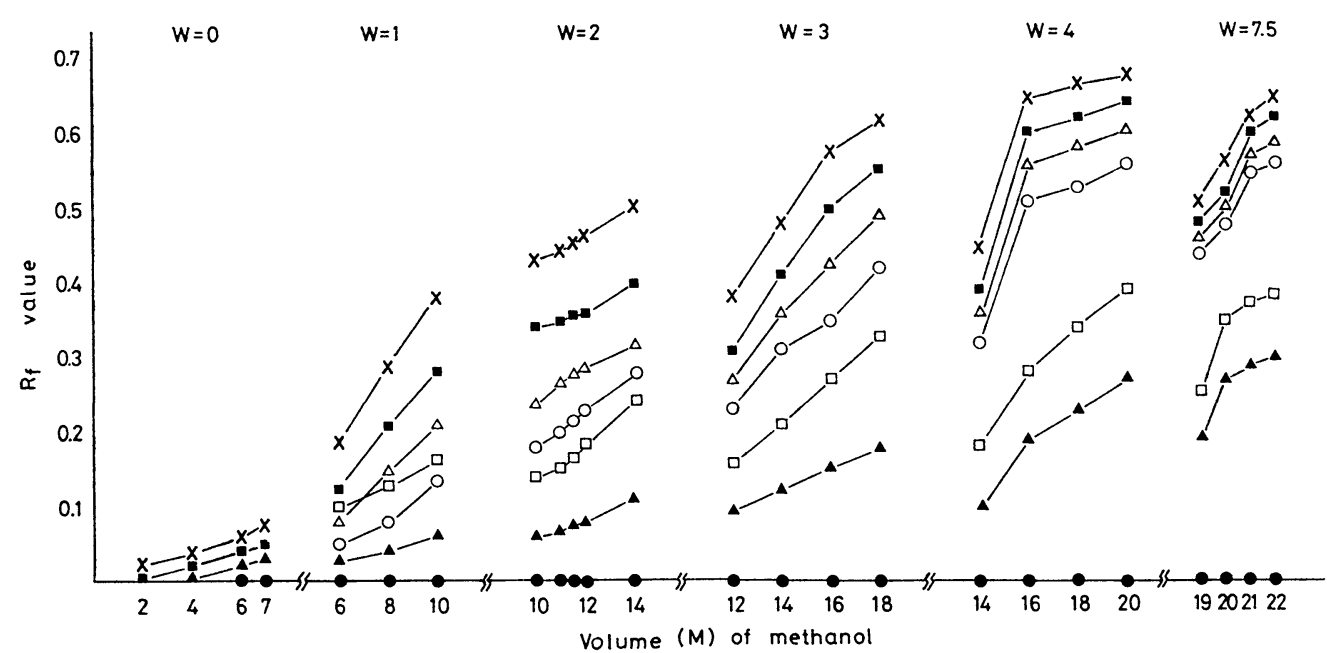

Fig. 1. Relationship between $R f$ values of sweetners and volume of methanol in mixture of $\mathrm{CHCl}_{3}-\mathrm{MeOH}-\mathrm{H}_{2} \mathrm{O}(15: \mathrm{M}: \mathrm{W})$ on thin layer chromatography $\times-\times$, Steviolbioside; $\bigcirc-\bigcirc$, Rebaudioside A; $-\longrightarrow$, Starch; $\mathbf{\square}-\mathbf{\square}$, Rebaudioside B; $\square-\square$, Glucose; $\triangle \longrightarrow \triangle$, Stevioside; $\Delta-\Delta$, Lactose.

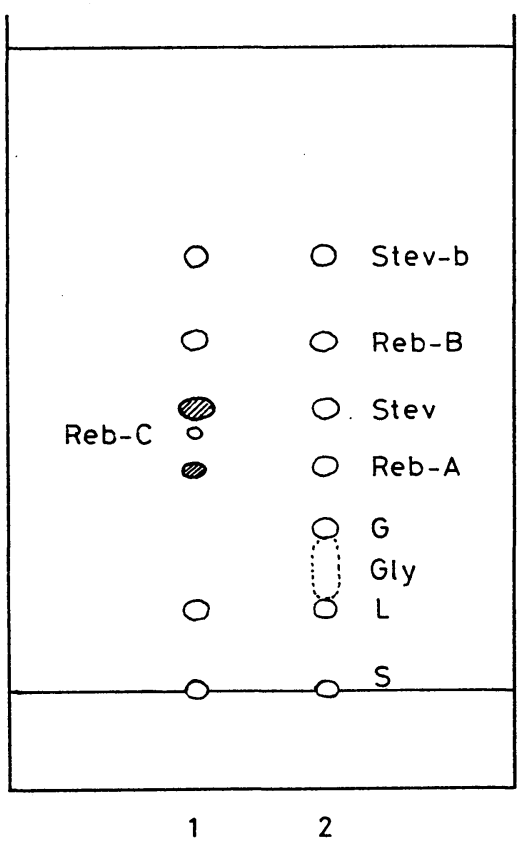

Fig. 2. Thin layer chromatograms of a natural sweetner preparation (1) and eight standard components (2)

Plate : Silica gel

Solvent : $\mathrm{CHCl}_{3}-\mathrm{MeOH}-\mathrm{H}_{2} \mathrm{O}(30: 23: 4)$

Detection : Anisaldehyde- $\mathrm{H}_{2} \mathrm{SO}_{4}$

Stev-b : Steviolbioside

Stev : Stevioside

Reb-A, B, C : Rebaudioside A, B, C

G: Glucose L: Lactose

S: Starch Gly: Glycyrrhizic acid
ールの比率が非常に高いとステビア成分および糖類はテ ーリングを起こすので，混合溶媒が分離せず，ステビフ 成分がテーリングしない範囲でクロロホルムを一定 (15 $\mathrm{ml})$ にし水 $(\mathrm{W})$ とメタノール (M) の溶媒量を検討した。 $\mathrm{W}=0,1,2,3,4,7.5$ の場合についてすなわちクロロホ ルムーメタノールー水 $(15: \mathrm{M}: 0),(15: \mathrm{M}: 1),(15:$ $M: 2),(15: M: 3),(15: M: 4),(15: M: 7.5)$ の混合 溶媒について，それぞれ溶媒が分離しない範囲で $\mathrm{M}$ の 量を変化させ，それらの溶媒で TLCを行った後，各成 分の $R f$ 值を求めた. その結果を Fig. 1 に示した. $\mathrm{W}=0$ のとき各成分ともほとんど原点近くに止まり，W および M の量が大きくなるにしたがいステビア成分お よび糖類の $R f$ 值は高くなったが, デンプンの Rf 值は どの溶媒系でも0であった，ステビア 4 成分および他の 糖類のスポットのまとまりが良く分離が良好であった溶 媒は $\mathrm{W}=3$ の $\mathrm{M}=16,18$ であるが, 同時に存在する天然 甘味料のグリチルリチン酸が Reb A の Rf 值と一致し 確認を妨害したので, $\mathrm{W}=2$ で $\mathrm{M}=11,11.5,12$ のらち ステビア成分の最も分離の良好な $\mathrm{M}=11.5$ を用いるこ とにした。 この展開溶媒クロロホルムーメタノール一水 (15:11.5:2) による Stev, Reb A, Reb B, Stev-b, Gly, G, L, S 各種標準溶液および試験溶液の TLCクロ マトグラムを Fig. 2 に示したが，各成分の $R f$ 值は， Stev-b : 0.45, Reb B : 0.36, Stev : 0.28, Reb A : 0.21, $\mathrm{G}: 0.17, \mathrm{~L}: 0.08, \mathrm{~S}: 0$ であった. またレバウディオサ イド C (Reb A の glucose が rhamnose に置換された 配糖体) ${ }^{1)}$ は, Stev および Reb A とよく分離した. ア ニスアルデヒドー硫酸で発色させた時の呈色は, ステビア 5 成分がすべて緑, Gが深緑, Lが深緑, Sが黑緑であ 
り， ，ステビア 4 成分の検出限界はそれぞれ $0.1 \mu \mathrm{g}$ で あった.なおグリチルリチン酸の $R f$ 值は $0.10 \sim 0.15$ で紫色に呈色するため，ステビア成分と区別できること が判明した。

\section{2. カラムクロマトグラフィーによるデンプンの除去 の検討}

デンプン含有試料をそのまま HPLC に付す場合，力 ラム分離に影響しカラムの寿命を短くする等問題がある ので，デンプンの除去法を検討した.

TLC の結果から，シリカゲルカラムでクロロホルム 一メタノール一水系の溶媒を用いればデンプンを除去で きると考えられた。そこで吸着剤にシリカゲルを用い, まずステビア成分および糖類をカラム上層に吸着させる 溶媒を検討した. Fig. 1 より各成分の $R f$ 值の低いク口 ロホルムーメタノール系 $(15: \mathrm{M})$ 溶媒が考えられた。 Mの值が小さい程良好だが，試験溶液が $50 \%$ の水を含 有するため (ステビア成分の溶解度が最も高い溶媒), M が 7 以下だと試験溶液注入時に溶媒分離を生じるので, $\mathrm{M}=7.5$ すなわちクロロホルムーメタノール (15:7.5) を用いることとした。 また溶出溶媒としては. ステビア 4 成分の $R f$ 值が高く, しかも 4 つのスポットが接近し ている溶媒系 $\mathrm{W}=7.5$ で $\mathrm{M}=19,20,21$ が考兄られた が,このうち $\mathrm{M}=19$ の場合は混合溶媒のバランスがく ずれやすく，また $\mathrm{M}=21$ はステビア成分のスポットの まとまりが悪くなる傾向を示したので， $M=20$ すなわ ちクロロホルムーメタノール一水（15:20:7.5）を用 いることにした。

ついで吸着溶媒にクロロホルムーメタノール (15： $7.5)$, 溶出溶媒にクロロホルムーメタノールー水 (15: $20: 7.5)$ を用いて，ステビア 4 成分の流出フラクショ ンを検討した．溶出液 $5 \mathrm{ml}$ ずつを分取し, 各フラクシ

Table 1. Recoveries of Stevioside and Rebaudioside A by Silica Gel Column Chromatography

\begin{tabular}{l|ccc} 
& $\begin{array}{c}\text { Added } \\
(\mathrm{mg})\end{array}$ & $\begin{array}{c}\text { Found } \\
(\mathrm{mg})\end{array}$ & $\begin{array}{c}\text { Recovery } \\
(\%)\end{array}$ \\
\hline \multirow{3}{*}{ Stevioside } & 0.25 & 0.218 & 87.2 \\
& & 0.219 & 87.9 \\
& \multirow{2}{*}{1.0} & 0.935 & 93.5 \\
& & 0.941 & 94.1 \\
& \multirow{2}{*}{2.5} & 2.329 & 93.2 \\
& & 2.360 & 94.4 \\
\hline \multirow{3}{*}{ Rebaudioside A } & \multirow{2}{*}{0.25} & 0.225 & 90.2 \\
& & 0.225 & 90.2 \\
& \multirow{2}{*}{1.0} & 0.947 & 94.7 \\
& \multirow{2}{*}{2.5} & 0.995 & 95.5 \\
& & 2.392 & 95.7 \\
& & 2.407 & 96.3
\end{tabular}

ョンを濃縮した後，TLC で確認したところ，5～15 ml の間にステビア 4 成分が溶出してくることが認められ た. したがって溶出液 0 25 $\mathrm{ml}$ を分取することにした. またデンプンについても同様に行ったところ，いずれの フラクションにもデンプンは確認されなかったので，シ リカゲルに吸着され除去されたと考える.

つぎに, Stev および Reb A の濃度 $0.25 \mathrm{mg}, 1 \mathrm{mg}$, $2.5 \mathrm{mg}$ についてそれぞれカラム回収実験を行ったとこ ろ, Table 1 のごとく良好な結果が得られた. また試料 $1 \mathrm{~g}$ について 3 回繰り返しカラム操作を行ったところ, Stev 4.73, 4. 68, 4.70 mg, Reb A 0.99, 1.00, $1.00 \mathrm{mg}$ と再現性も良好であった。

\section{HPLC による分離条件の検討}

ステビア成分が配糖体であることから，一般に糖分離 に用いられるシリカゲル担体に $\mathrm{NH}_{2}$ 基を導入した順相 系のカラムを用いて検討を行った．移動相にアセトニト リル一水系を用いStev, Reb A および Reb C の分離 条件を検討した．Reb C の標準品が得られなかったの で, Stev, Reb A および Reb C を含有するステビア 糖 $\mathrm{K}$ (ステビア甘味成分 $50 \%$ 含有) を用いた. ステビ ア 3 成分の分離が最も良好であったアセトニトリル一水 の溶媒比は $83: 17$ である。この移動相による StevReb A 標準溶液およびステビア糖 $\mathrm{K}$ のクロマトグラム を Fig. 3 に示した.なお Reb B, Steb-b，G，および $\mathrm{L}$ 等は検出波長 $210 \mathrm{~nm}$ に吸収をもたないため,これら はStev および Reb A の定量を妨害しないことが判っ た.

市販甘味料製剤中には他にカラムクロマトグラフィー で除去できない酸性物質 (有機酸塩, グリチルリチン酸,

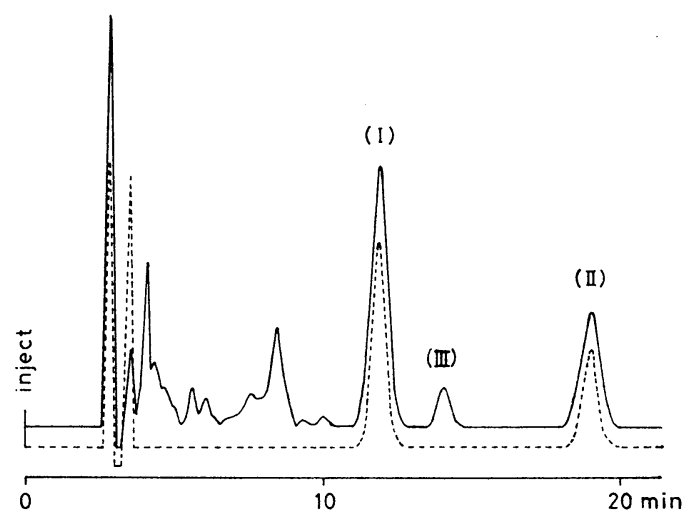

Fig 3. HPLC chromatograms of stevia components in natural sweetner preparation and some standard components

Column, Unisil Q- $\mathrm{NH}_{2}(5 \mu, 4 \mathrm{~mm} \times 25$ $\mathrm{cm})$; Eluent, $\mathrm{CH}_{3} \mathrm{CN}-\mathrm{H}_{2} \mathrm{O}(83: 17)$ Flow rate, $1.2 \mathrm{ml} / \mathrm{min}$; Detector, UV $210 \mathrm{~nm}$

(I) Stevioside, (II) Rebaudioside A, (III) Rebaudioside C; ---, Standard; - , Sample 
サッカリンなど）が配合されているが，これらは HPLC 分析の際, UnisilQ- $\mathrm{NH}_{2}$ に吸着されカラムの寿命を短 くするので, 同系のプレカラム (UnisilQ- $\mathrm{NH}_{2}, 4 \mathrm{~mm} \times$ $5 \mathrm{~cm})$ を用い，これを適宜取り替えることにより本カラ ムを長時間保持することができた。

\section{4. 検量線}

Stev および Reb A とも $0.5 \sim 5 \mu \mathrm{g}$ の範国で良好な 直線性を示した. (Fig. 4)

\section{5. 市販天然甘味料中のステビア成分の定性および定 量}

市贩天然甘味料製剂 14 種について TLC を行った結 果, 14 種とも, Stev, Reb A, Reb C, Reb B および Stev-b の 5 成分が確認された.

Stev および Reb A の定量結果を Table 2 に示した.

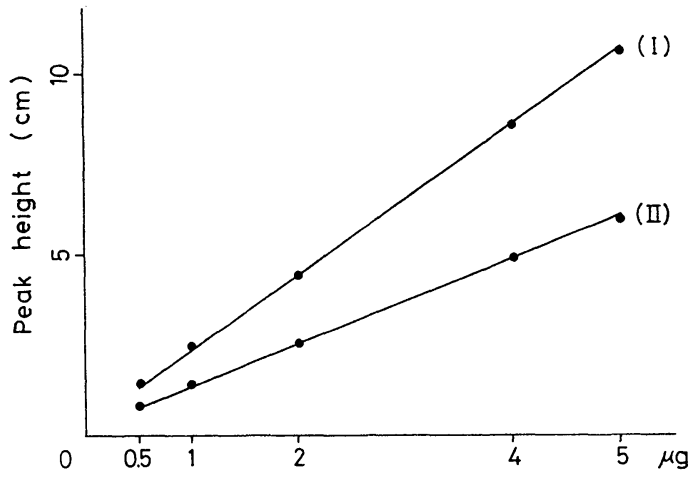

Fig. 4. Calibration curves of stevioside (I) and rebaudioside $A$ (II) by $H P L C$

Table 2. Contents of Stevioside and Rebaudioside $A$ in Natural Sweetner Preparation

\begin{tabular}{c|ccc} 
Sample & $\begin{array}{c}\text { Stevioside } \\
(\%)\end{array}$ & $\begin{array}{c}\text { Rebaudioside } \\
\text { A } \\
(\%)\end{array}$ & $\begin{array}{c}\text { Total of stevia } \\
\text { components } \\
(\%)\end{array}$ \\
\hline 1 & 4.20 & 3.59 & 8.59 \\
2 & 1.57 & 0.96 & 4.32 \\
3 & 2.03 & 1.46 & 5.31 \\
4 & 2.59 & 0.91 & 5.79 \\
5 & 7.10 & 3.09 & 12.6 \\
6 & 3.81 & 0.94 & 7.48 \\
7 & 4.77 & 1.05 & 8.06 \\
8 & 0.60 & 0.26 & 1.38 \\
9 & 4.63 & 1.81 & 8.83 \\
10 & 2.36 & 0.82 & 5.00 \\
11 & 2.16 & 1.66 & 4.94 \\
12 & 37.9 & 11.9 & 70.7 \\
13 & 0.47 & 0.18 & 1.23 \\
14 & 5.12 & 1.56 & 6.80
\end{tabular}

Stev 含量は $0.47 \sim 37.9 \%$, Reb A 含量は $0.26 〜 11.9 \%$ で，ほとんどの試料中から Stev が Reb A の約 2 倍量 検出された。また Stev と Reb A の含量の和は総ステ ビオサイド8)の約 $70 \%$ に相当し，これらはステビア成 分の主成分であることが判明した。

\section{まとめ}

天然甘味料製剂中のステビア成分を定性する目的で TLC 法を, 主甘味成分の Stev および Reb A を定量 する目的でカラムクロマトグラフィーによるクリーンア ップ法および HPLC 定量法を検討した. 試料を $50 \mathrm{v} / \mathrm{v}$ \%×タノールに溶かし，そのままTLCに付した，展開 溶媒にクロロホルムーメタノール一水系を用い, その溶 媒比を種々検討したところ，30:23：4 が最も良好であ った，発色試薬にアニスアルデヒド硫酸を用いた，ステ ビア成分はすべて緑色を呈し，その検出限界はそれぞれ $0.1 \mu \mathrm{g}$ であった.

HPLC の際妨害するデンプンを除去する目的でシリ カゲルカラムクロマトグラフィーを検討した．溶出溶媒 にクロロホルムーメタノールー水 $(30: 40: 15)$ を用い たところ，ステビア成分は $0 \sim 15 \mathrm{ml}$ に溶出し，デンプ ンは吸着され溶出しなかった. カラム回収率は $2.5 \mathrm{mg}$ 添加で Stev 93.8\% および Reb A 96.0\% と良好で再 現性も良かった，HPLC ではシリカゲル担体に $\mathrm{NH}_{2}$ 基 を導入した順相系のカラムを用い，移動相にアセトニト リル一水 $(83: 17)$ を用いて良好な分離が得られた。検 量線は $0.5 \sim 5 \mu \mathrm{g}$ の範囲で直線性を示した.

市販品 14 種につき本法を応用したところ，すべての 製品中から Stev, Reb A, Reb C, Reb B, Stev-b の 5 成分が検出され，主甘味成分の Stev 含量は $0.47 \sim 37.9$ \%, Reb A 含量は 0.26〜 11.9\%であった. Stev と Reb $\mathrm{A}$ の含量の和は総ステビオサイドの約 $70 \%$ に相当し, これらはステビア甘味料の主成分であることが判明し た.

なお本研究の要旨は日本食品衛生学会第39回学術讙演 会（1980年 5 月，東京）において発表した。

文献

1) Sakamoto, I., Yamasaki, K., Tanaka, O.: Chem. Pharm. Bull., 25, 3437 3439 (1977).

2) Kohda, H., Kasai, R., Yamasaki, K., Marukami, K., Tanaka, O.: Phytochemistry, 15, 981 983 (1976).

3) Sakamoto, I., Yamasaki, K., Tanaka, O.: Chem, Pharm. Bull., 25, 844 846 (1977).

4) Hashimoto, Y., Moriyasu, M.: 生薬学雑誌 32, 209 211 (1978).

5) 坂本征則, 神田博史, 村上国子, 田中 治：薬 誌. 95, 1507〜1510 (1975).

6) 三橋 博, 上野純子，住田哲也：同上，95，127 $\sim 130$ (1975). 
7）鍋田憲助，伊藤硎治，杉沢 博：農化．51，179 $\sim 181$ (1977).

8）日本食品添加物 団体 連合会：天然食品添加物規
格, (1977).

9）岩村淳一，木下了彦，平尼子之吉：農化．54， 195 200 (1980). 